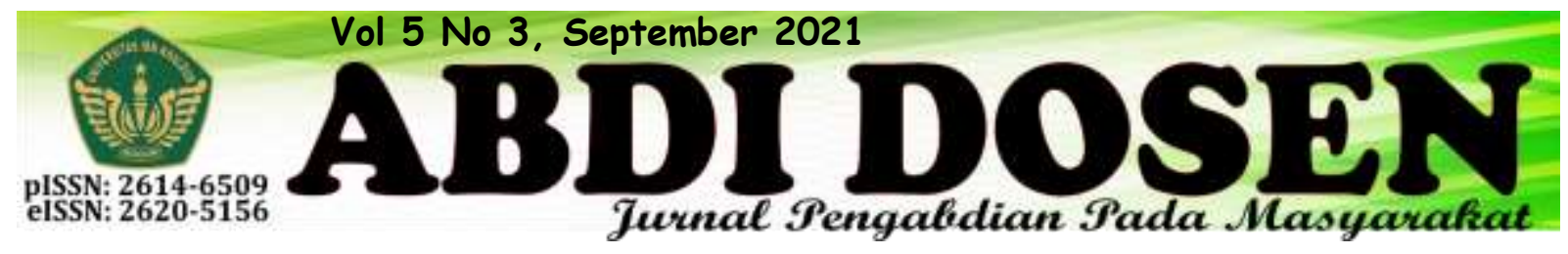

\title{
PERSEPSI, SIKAP DAN PERILAKU MASYARAKAT TERHADAP PROGRAM 3 M DALAM MENGHINDARI PERSEBARAN COVID-19 (Studi kasus Masyarakat Desa Sutawinangun Kecamatan Kedawung Kabupaten Cirebon)
}

\author{
Somantri ${ }^{1}$, dan Muhammad Iqbal Al Ghozali \\ somantriperbangkara@gmail.com ${ }^{1}$ \\ alghazalimuhammad0@gmail.com ${ }^{2}$ \\ Institut Agama Islam Bunga Bangsa Cirebon ${ }^{1,2}$
}

\begin{abstract}
ABSTRAK
Pandemi Covid-19 dengan eksistensitas tinggi dan penyebarannya signifikan mengharuskan adanya upaya memutus matarantai sebarannya diantaranya dengan 3M (mencuci tangan, memakai masker dan menjaga jarak). Aspek yang dikaji adalah; persepsi, sikap dan perilaku masyarakat terhadap pelaksanaan program 3M dalam menghindari persebaran covid-19 di Desa Sutawinangun Kecamatan Kedawung Kabupaten Cirebon. Penelitian kualitatif dipilih sebagai metode untuk mengekplorasi dan memahami makna yang dianggap berasal dari masalah sosial atau kemanusian, berfokus pada makna individual, dan menerjemahkan komplesitas suatu persoalan. Data deskriptif dikembangkan dari hasil perolehan sejumlah informasi tertulis maupun lisan dari hasil pengamatan. Setelah adanya anggota masyarakat yang terpapar dan dinyatakan zona merah covid-19, kemudian ada rencana relokasi penderita covid di Sutawinangun baru tumbuh kesadaran melaksanakan 3M. Bagaimana agar masyarakat terbuka dan siap bekerjasama pada upaya mempercepat penanganan dan pencegahan virus corona untuk kembali merasakan situasi kondusif. Upaya menyelesaikan pandemi ini mutlak diperlukan dengan 3M dan \#dirumahaja dibarengi tindakan kongkret untuk melakukan aktivitas di rumah dalam menjaga kesehatan. Solidaritas masyarakat menjadi faktor penting sebagai modal sosial untuk melawan Covid-19. Masyarakat berfokus menerapkan 3M, pola hidup bersih dan sehat serta mengurangi mobilitas kerumunan dalam masyarakat untuk terhindar dari virus tersebut
\end{abstract}

Kata Kunci:: Persepsi, Sikap, Perilaku masyarakat, $3 M$.

\section{PENDAHULUAN}

Penelitian ini dilatarbelakangi adanya tempat pondokan yang posisinya selain dekat dengan lembaga Pendidikan/ kampus, juga di tengah perumahan penduduk rencananya dijadikan sebagai tempat isolasi penderita covid-19 yang kemudian ditentang oleh warga sehingga menimbulkan suasana kurang nyaman.
Pihak pemerintahan desa memfasilitasi pertemuan untuk membahas masalah tersebut sebab ada ketidakjujuran dan perlunya etika pihak tertentu terhadap rencana tersebut sehingga memicu keadaan yang tidak nyaman.

Penolakan isolasi di tengah lingkungan warga banyak terjadi di 
berbagai tempat. Contoh penolakan diantara Warga Sabang menolak hotel Max One Sabang di Jakarta Pusat menjadi lokasi isolasi mandiri bagi pasien Covid-19 yang tanpa gejala (Kompas, 2020). Kemudian penolakan lainnya yaitu belum digunakan sebagai shelter isolasi mandiri Corona Virus Disease 2019 (Covid-19), namun alih fungsi rusunawa Gemawang mendapat penolakan dari warga. Terlihat dari adanya coretan tolak karantina COVID-19 (Radar Jogja, 2020). Adapun Isolasi sendiri adalah pemisahan orang sakit dari orang sehat yang dilakukan di fasilitas pelayanan kesehatan untuk mendapatkan pengobatan dan perawatan (Telaumbanua, 2020).

Setidaknya kita bisa melihat betapa pemerintah kewalahan dalam menghadapi persoalan paparan covid-19 ini sehingga membutuhkan kebersamaan dalam penangannya termasuk dalam memenuhi kebutuhan tempat isolasi yang sudah menjadi tuntutan krusial dengan tidak hanya mengandalkan pihak pemerintah semata. Pemerintah sebenarnya telah membuat regulasi masalah pandemic covid-19 ini namun karena paparannya di luar kontrol sarana dan prasarana sehingga memerlukan vendor yang tepat dan bisa memenuhi harapan pemerintah dan warga masyarakat. Padahal Urgensi pembentukan aturan terkait dengan pencegahan Covid19 ini wajib dibentuk dalam Peraturan Pemerintah dan Peraturan Menteri Kesehatan (Telaumbanua, 2020).

Pemberitaan yang masif terkait bahaya pandemic covid-19 sangat memengaruhi akal pikiran manusia yang secara sadar akan memunculkan naluri keselamatan diri dan orang-orang yang yang disayanginya. Dampak dari pemberitaan dimaksud memunculkan persepsi, sikap dan perilaku siapapun sebagai respon atas stimulus pemberitaan. Teori Skinner ini disebut teori "S-O-R" atau Stimulus - Organisme - Respon menjadi kata kunci untuk Mengembangkan deskripsi ini. Pemberitaan pandemic covid19 merupakan stimulus dan persepsi, sikap dan perilaku merupakan dari respon sadar manusia.

Terkait dengan pandemic covid-19 yang berlatar belakang aneka macam menumbuhkan persepsi tersendiri pada masyarakat. Information society terbangun di atas dunia maya yang memang merangsang siapaun untuk melek media. Jika tidak melek maka terlindas keadaan menjadi hukum dalam tata pergaulan global saat ini. Melek menjadi titik kritis dan respon positif pribadi sebagai bentuk kesadaran masing-masing orang dan bisa memengaruhi sikap hidupnya. Melek bisa berarti dapat melihat . Melek bisa dipahami dapat melihat keadaan dan waspada dengan keadaan diri. Sementara penulis memahami melek media adalah kesadaran seseorang dalam keterlibatan pemberitaan sesuatu yang akan memengaruhi dirinya. Melek media menjadi keunggulan potensi tersembunyi diri (self hidden potential excellence) seseorang. Melek media menyadarkan setiap orang untuk mempertimbangkan dan memperhitungkan isi berita atau materi. Selain melalui media juga ada desas-desus penempatan penderita/terdampak covid-19 di lokasi yang diberitakan media di atas.

Kepala Badan Nasional Penanggulangan Bencana (BNPB) selaku Ketua Satuan Tugas (Satgas) Penanganan Covid-19 Indonesia, Letjen TNI Doni Monardo pada pertemuan virtual (zooming) Fellowship (Kebersamaan) Jurnalisme Perubahan Perilaku (FJPP) baru-baru ini mengatakan, berdasarkan penelitian atau survei yang dilakukan Biro 
Pusat Statistik (BPS) Pusat medio 7-14 September 2020, sekitar 44 juta jiwa penduduk Indonesia tidak percaya Covid19 dan tidak yakin dirinya bisa tertular Covid-19. Jumlah penduduk Indonesia yang tidak percaya Covid-19 tersebut mencapai $16 \%$ dari sekitar 268 juta jiwa penduduk Indonesia saat ini.

Dikatakan, sikap apatis tentang bahaya Covid-19 tersebut membuat orang enggan mematuhi protokol kesehatan Covid-19. Ketidak-pedulian warga masyarakat terhadap 3M dan melakukan isolasi mandiri membuat potensi penularan Covid-19 di masyarakat akan tetap tinggi seperti terjadi di beberapa negara besar (Beritasatu, 2020).

Secara sosiologis masyarakat tergugah kesadaran sosialnya untuk memperhitungkan keberadaan isolasi pesakitan tersebut yang berdampak pada masyarakat sekitarnya. Secara psikologis pasti mereka akan menyimpulkan berbagai persepsi dan sikap serta berprilaku untuk merespon keadaan.

Selain latar belakang dan persoalan sosial di atas tampaknya penting untuk dianalisis kesadaran pertahanan diri masing-masing warga untuk tidak terpapar pandemic covid-19 melalui program 3M

\section{METODE}

Metode penelitian yang diambil adalah penelitian kualitatif. Penelitian kualitatif adalah metode untuk mengekplorasi dan memahami makna yang dianggap berasal dari masalah sosial atau kemanusian, berfokus pada makna individual, dan menerjemahkan komplesitas suatu persoalan (Craswell, 2009). Adapun jenis penelitian yang dipilih adalah penelitian studi kasus.

Penelitian ini dilaksanakan di Desa Sutawinangun Kecamatan Kedawung
(Mencuci tangan, Memakai masker, Menjaga jarak). Kesadaran ini menjadi kunci sekaligus parameter kebersaan untuk mengurangi resiko yang memiliki efek domino terhadap lingkungannya. Kesadaran 3M menjadi kecerdasan sosial sebagai anggota warga masyarakat. Pemerintah dengan gencar telah melakukan penyadaran akan pentingnya 3M melalui berbagai macam media dan teknik yang dipandang efektif. Akan tetapi apa yang terjadi dalam masyarakat sering juga ditemukan fakta tidak sadar diri dengan 3M. Pengabaian masih banyak terjadi dengan kasat mata kita bisa melihat sehingga seharusnya ada analisis khusus agar pandemic covid-19 bisa segera berlalu.

Penelitian ini mengangkat masalah pandemic covid-19 yang aktual dengan latar belakangnya banyak terjadi di seanterio dunia melalui deskripsi Persepsi, Sikap dan Perilaku Masyarakat Terhadap Program 3M (Mencuci Tangan, Memakai Masker dan Menjaga Jarak) dalam Menghindari Persebaran Covid-19 (Studi kasus Masyarakat Desa Sutawinangun Kecamatan Kedawung Kabupaten Cirebon).

Kabupaten Cirebon selama 30 hari, dimulai tanggal 30 November sampai dengan 30 Desember 2020.

Subjek penelitian adalah warga Desa Sutawinangun Kecamatan Kedawung Kabupaten Cirebon dari berbagai kalangan dengan jumlah observer 120 orang. Adapun sumber data dalam penalitian ini adalah meliputi data primer diperoleh dari informasi yang di berikan oleh informan yang bersangkutan. Sumber dari data primer adalah sumber yang langsung 
memberikan data kepada peneliti (Bungin, 2001).

Teknik pengumpulan data dalam penelitian inilah dengan menggunakan teknik wawancara dengan melakukan

\section{HASIL DAN PEMBAHASAN}

Pelaksanaan 3M sebagai protokol kesehatan dan pencegahan covid-19 sebenarnya merupakan program nasional dan internasional yang implementasinya dilaksanakan pada masing-masing satuan tugas (satgas) atau gugus covid-19 di masing-masing daerah. Berdasarkan informasi yang kami dapatkan bahwa pelaksanaan pencegahan covid-19 di Desa Sutawinangun telah dibentuk gugus tugasnya. Petunjuk pelaksanaan dan petunjuk teknisnya mengacu pada program tugas gugus covid-19 tingkat nasional.

Penyebaran virus Corona atau COVID-19 di Indonesia harus ditekan semaksimal mungkin. Salah satu cara utamanya adalah dengan menerapkan perilaku hidup disiplin. Maka, selalu dengan melakukan langkah 3M sebagai upaya mencegah sekaligus memutus rantai penularan COVID-19. Membiasakan dan mewajibkan diri untuk mematuhi protokol kesehatan merupakan salah satu kunci agar virus COVID-19 dapat ditekan penyebarannya. Namun, dibutuhkan perilaku disiplin dari diri sendiri, juga sangat perlu untuk dilakukan secara kolektif dengan penuh kesadaran. Demikian halnya berlaku di Desa Sutawinangun.

Gugus covid-19 sejak terbentuk telah melaksanakan tugas sesuai dengan panduan yang diterapkan secara dinamis dan kreatif dengan tetap mengedepankan pendekatan persuasif dan santun namun tegas dan penuh prinsip mengacu pada protokol Kesehatan. tanya jawab langsung dengan informan terkait rumusan masalah di atas, di tambah lagi dengan dokumentasi sebagai data tambahan untuk proses selanjutnya.

\section{Acuan Sosialisasi Pelaksanaan 3M dalam Memutus Matarantai Covid- 19.}

Sosialisasi dan pelaksanaan 3M di Sutawinangun dipimpin oleh Kepala Desa (Ibu Dias Fakhnuritasari, M.Pd.) bersama Satuan Tugas Penanganan COVID-19. Acuan program pelaksanaan $3 \mathrm{M}$ yakni sebagai berikut :

a. Panduan Memakai Masker

1) Semua orang harus memakai masker, terutama jika di luar rumah.

2) Sebelum memakai masker, cuci tangan pakai sabun dan air mengalir (minimal 20 detik).

3) Bila tidak tersedia air, gunakan cairan pembersih tangan (minimal alkohol 60\%).

4) Pasang masker untuk menutupi mulut dan hidung.

5) Pastikan tidak ada sela antara wajah dan masker.

6) Hindari menyentuh masker saat digunakan.

7) Bila menyentuh masker, cuci tangan pakai sabun dan air mengalir minimal 20 detik, atau bila tidak ada, gunakan cairan pembersih tangan (minimal alkohol 60\%).

8) Jangan sentuh atau buka-tutup masker saat digunakan.

9) Ganti masker yang basah atau lembab dengan masker baru. 
10) Masker medis hanya boleh digunakan satu kali saja.

11) Buang segera masker 1x pakai di tempat sampah tertutup atau kantong plastik usai dipakai.

12) Masker kain 3 lapis dapat dipakai berulang, tapi harus dicuci dengan deterjen usai dipakai.

13) Saat membuka masker: lepaskan dari tali belakang dan jangan sentuh bagian depan masker.

14) Cuci tangan setelah menyentuh atau membuang masker.

15) Perlu diingat, penggunaan masker yang keliru justru meningkatkan risiko penularan. Pada awal-awal penyebaran pandemi ini masker mengalami kelangkaan. Hal tersebut karena kepanikan masyarakat akan penyebaran virus corona yang cepat yang ditularkan melalui udara sehingga untuk mengantisipasinya yaitu dengan menggunakan masker. Kelangkaan masker membuat pemerintah membatasi penggunaan masker medis diperuntukkan bagi tenaga kesehatan sementara bagi masyarakat umum cukup menggunakan masker kain (Armiani et al. 2020). Masker juga harus digunakan apabila sedang mengalami gejala batuk dan pilek, karena berfungsi dalam menyaring udara yang masuk ke dalam hidung dan meminimalisir penyebaran virus yang diakibatkan oleh pilek dan batuk (Sholikah and Suni 2020).

b. Panduan Mencuci Tangan

1) Basahi tangan dengan air mengalir.

2) Sabuni tangan.
3) Gosok semua permukaan tangan, termasuk telapak dan punggung tangan, sela-sela jari dan kuku, selama minimal 20 detik.

4) Bilas tangan sampai bersih dengan air mengalir.

5) Keringkan tangan dengan kain bersih atau tisu pengering tangan yang harus dibuang ke tempat sampah segera setelah digunakan.

6) Sering cuci tangan pakai sabun, terutama sebelum makan, usai batuk atau bersin, sebelum menyiapkan makanan, dan setelah ke kamar mandi.

7) Biasakan mencuci tangan pakai sabun setelah dari luar rumah atau sebelum masuk sekolah dan tempat lain.

8) Bila sabun dan air mengalir tidak ada, gunakan cairan pembersih tangan berbahan alkohol (minimal 60\%).

c. Panduan Menjaga Jarak

1) Selalu menjaga jarak fisik lebih dari 1 meter dengan orang lain.

2) Tetap berada di rumah sesuai panduan pemerintah, kecuali ada keperluan mendesak.

3) Bekerja, belajar dan beribadah di rumah.

4) Keluar hanya untuk belanja hal penting atau pengobatan, itu pun seminimal mungkin.

5) Gunakan masker saat di luar rumah.

6) Sebisa mungkin hindari penggunaan kendaraan umum.

7) Tunda atau batalkan acara berkumpul bareng keluarga besar atau teman 
8) Komunikasi tatap muka bisa dilakukan via telepon, internet, media sosial, dan aplikasi

9) Tunda atau batalkan acara pertemuan, konser musik, pertandingan olahraga, kegiatan keagamaan, dan kegiatan lain yang mengundang orang banyak.

10) Gunakan telepon atau layanan online untuk menghubungi dokter dan fasilitas lain.

11) Kalau mengalami demam, merasa lelah dan batuk kering, lakukan isolasi diri.

12) Semua orang harus melakukan physical distancing untuk mencegah penularan COVID19

13) Jaga jarak harus lebih ketat jika untuk melindungi orang yang berisiko

14) Orang yang berisiko, yaitu: berusia 60 tahun lebih; atau memiliki penyakit penyerta seperti sakit jantung, tekanan darah tinggi, diabetes, kanker, asma dan paru; ibu hamil.

\section{Persepsi, Sikap dan Perilaku Masyarakat Sutawinangun terha- dap Pelaksanaan 3M dan Pemahaman tentang Covid-19}

Semua apa yang digagas dan diimplementasikan gugus covid-19 Desa Sutawinangun mendapatkan respon sebagaimana dijelaskan di awal terkait teori Skinner ini disebut teori "S-O-R" atau Stimulus - Organisme Respon. Dari teori tersebut dapat dianalisis dan dideskripsikan beberapa simpulan terkait pesepsi, sikap dan perilaku masyarakat dengan adanya upaya dan pelaksanaan $3 \mathrm{M}$ dan
Pemahaman tentang Covid-19 bisa mencapai sasaran dan hasil maksimal yakni masyarakat yang terbebas dari pandemic covid-19.

Persepsi tentang covid-19 bagi warga masyarakat Sutawinangun yaitu penyakit yang disebarkan dari Cina yang berhubungan dengan pernafasan. Penyakit itu sangat berbahaya, mudah menular melalui udara dan kontak fisik. Penularannya sangat cepat dan belum ada obatnya secara khusus. Tanda dan gejala umum infeksi COVID-19 antara lain gejala gangguan pernapasan akut seperti demam, batuk dan sesak napas (Hasana, Sumarni dan Mulyadi, 2020).

Persepsi di atas menunjukkan pengetahuan masyarakat Sutawinang -un cukup baik dan penting dijadikan sebagai modal sosial pemerintah dalam memahampi persepsi masyarakat terkait dengan covid-19. Setidaknya ada pembelajaran yang sukses dari gugus covid19 dalam mensosialisasikan masalah $3 \mathrm{M}$ dan pemahaman tentang covid-19 pada masyarakat oleh pemerintah melalui berbagai cara dan model sosialisasinya.

Upaya yang dilakukan warga Sutawinangun agar tidak tertular virus covid-19 disimpulkan; minum vitamin, pakai masker, mencuci tangan, jaga jarak, pola hidup sehat, olahraga teratur, berjemur dipagi hari, menjalankan 3M. hal tersebut sudah sesuai dengan yang dihimbau oleh WHO bahwa semua masyarakat untuk menjaga kesehatan dan melindungi yang lain dengan melakukan sering mencuci tangan, melakukan social 3 Prosiding Seminar Nasional Hardiknas distancing, indari menyentuh mata, 
hidung dan mulut, menjaga kebersihan diri, jika merasa demam, batuk dan sesak napas, segera mencari bantuan medis dan terus perbaharui informasi Anda (Karo, 2012).

Upaya di atas menunjukkan kesadaran bahwa masyarakat prinsipnya koopratif dalam upaya memutus rantai pandemic covid-19 dengan cara dan upaya mereka lakukan di atas. Upaya ini cukup efektif menekan ledakan covid-19 di Sutawinangun. Setidaknya diujung bulan Desember tepatnya tanggal 30 Desember 2020, pukul 11.45 tidak ada berita masuk tentang akibat covid-19 saat Kepala Desa diminta konfirmasi terkait pandemic tersebut.

Terkait dengan perubahan dalam pergaulan sehari-hari setelah adanya berita bahaya covid-19 di dalam lingkungan masyarakat yaitu melakukan social distancing yang dilakukan Pemerintah selanjutnya adalah meliburkan siswa, mahasiswa dan pekerja dan menggantinya dengan belajar dari rumah, bekerja dari rumah, dan beribadah di rumah (Harirah dan Rizaldi, 2020.). Adapun responden memberi jawaban kurangnya aktivitas diluar dan jarang adanya kegiatan-kegiatan yang mengundang banyak orang. saling menjaga jarak dan jarang adanya lagi kerumunan. "Ada dan banyak perubahan biasanya kita kumpulkumpul atau berkerumun, sekarang tidak bisa krena kita harus jaga jarak." (Andri, 2020) lain;

Ada juga yang berpendapat

"Belum terlalu, karena warga sekitar masih ragu dan mungkin belum tahu bahaya virus covid ini” (Agung, 2020). Sementara bagi Yani (2002) terkait dengan perubahan pergaulan setelah ada covid-19 menjawab; "Iya ada, ketika bertemu dengan teman atau kerabat dekat kita tidak berjabat tangan dan jika setelah keluar rumah selalu mencuci tangan dengan air yg mengalir. Diusahakan jika tidak begitu penting tetap diam dirumah".

Penuturan tersebut menyiratkan ada pemahaman berbeda di masyarakat. Hal ini tentu perlu adanya sosialisasi lanjutan agar pemahaman tentang covid-19 dan dampaknya terhadap masyarakat bisa menjadi pemahaman bersama. Selain itu, sikap yang terlontar dari bagian masyarakat harus didalami oleh gugus covid-19 dalam semua level. Sinyal ini menunjukkan ada bagian penting ya ng harus menjadi titik tekan penyadaran bersama.

Terkait dengan upaya dari pemerintah dalam menanggulangi bahaya covid-19, responden memberikan jawaban sebagaimana simpulan berikut; Iya ada (upaya pemerintah dalam penanggulangan bahaya covid-19; red.), penyemprotan disinfektan, membagikan masker, menerapkan protokol kesehatan contohnya untuk wajib masker dan membatasi jam operasional mall, pasar, minimarket, dll., membagikan masker gratis dan membatasi kegiatan jam malam dan melakukan PSBB., melakukan patroli oleh pihak kepolisian yaitu membubarkan setiap kerumunan di tempat tempat umum. 
Pernyataan di atas sebagai bentuk pengakuan dan kesaksian masyarakat yang menunjukkan bahwa pemerintah terlibat langsung pada upaya-upaya menyadarkan masyarakat akan bahaya sebaran covid-19 yang berefek domino pada kehidupan lainnya.

Sebagaimana diungkap
dilatarbelakangi adanya tempat
pondokan yang posisinya selain dekat dengan lembaga Pendidikan/kampus, juga di tengah perumahan penduduk rencananya dijadikan sebagai tempat isolasi penderita covid-19 yang kemudian ditentang oleh warga sehingga menimbulkan suasana kurang nyaman hubungan antara berbagai pihak. Warga masyarakat menuturkan dengan bahasanya sendiri bisa disimpulkan mereka menyatakan;

"Tidak Setuju ya karena kan katanya virus itu menyebar lewat udara, tidak Setuju aja, bahaya juga dong buat lingkungan sekitar, Tidak karena kan virus bisa menyebar ke lingkungan kita, tidak Setuju , takut menyebar ! Tidak setuju, karena terlalu rawan untuk terpapar dengn covid$19 "$.

Paparan di atas merupakan pernyataan beberapa responden yang kemudian mengkristal jadi bentuk penolakan adanya isolasi penderita covid-19 di lingkungannya. Ini pula yang kemudian memicu adanya protes terhadap lokasi isolasi

Walau demikian ternyata ada juga warga yang menyampaikan pendapatnya berbeda; "Pada dasarnya apabila ada hotel yang dijadikan RS khusus Covid 19 itu tidak masalah melihat jumlah pasien yang terkena covid 19 sangat banyak dibanding fasilitas ruang di rumah sakit yang kurang sehingga butuh tempat untuk menampung agar pasien tidak terlantar dan segera bisa ditangani dengan mensiasati hotel di jadikan RS khusus Covid 19." Pembaca bisa memahami pola pemikiran tersebut sebagai bentuk kesadaran ingin membantu namun dibutuhkan etika dalam membangun hubungan baik dengan warga masyarakat untuk niat yang sama dalam mengatasi pandemic covid-19 bersama warga.

Dari pernyataan di atas tampaknya perlu kearifan pemerintah dalam memilih tempat isolasi dan bisa kooperatif dengan berbagai pihak yang sebenarnya peduli dengan musibah yang berdampak pada berbagai macam kehidupan. Di satu sisi masyarakat pun bisa memaklumi dan menyadari bentuk kooperatif dalam penempatan isolasi dengan beberapa standar dan syarat yang bisa diperhitungkan lokasinya yakni, jauh dari rumah penduduk, jauh dari lokasi berkumpulnya warga, dan tidak menampakkan kesan asal-asalan memilih lokasi walau mungkin beralasan keterdesakkan kebutuhan akan sarana.

Kejelasan tingkat kooperatif jika di tes rapid dan swab, tampaknya masyarakat beragam dalam meresponnya. Mereka ada yang menjawab secara sadar, ada juga yang sepertinya menghadapi keterdesakkan dan lucu. Mereka menjawab, 
"Setuju kalo tidak bayar, Setuju kalo memang diharuskan, Setuju kalo memang diharuskan dan gratis, setuju karena sebenarnya test swab atau rapid tidak hanya untuk orang yang positif covid saja tetapi yg tidak terkena pun boleh rapid atau swab untuk mengetahui kondisi kita, setuju karena test swab atau rapid agar mengetahui kita terjangkit positif covid atau tidak, Setuju demi Kesehatan."

Selain pernyataan di atas ada juga beberapa responden menjawab, "Tidak, karena saya merasa sehat dan tidak ada gejala yg mengarah pada tanda-tanda covid-19, Engga lah takut!". Dengan pernyataan tersebut mengindikasikan pentingnya kesada -ran masyarakat terhadap pentingya tes rapid dan swab untuk memastikan langkah berikutnya dalam menanggulangi pandemic covid-19.

Berkenaan dengan Konsep $D i$ Rumah Saja (DRS), ternyata respon masyarakat beragam sebagaimana terungkap berikut,

"Tidak setuju kan kita juga harus bekerja, Engga setuju, karena kita butuh makan jd harus tetep kerja, Tidak setuju, ya nanti gak jualan dan gak punya uang, Tidak, Karena saya seorang pekerja yg mempunyai tanggung jawab penuh pada pekerjaan saya, jika saya harus diam dirumah itu artinya saya tidak akan bekerja. Saya mempunyai keluarga yg harus tetap di penuhi kebutuhannya dan pekerjaan adalah amanah untuk saya. Apapun resikonya Insya Allah saya jalanin. Yang terpenting saya selalu memenuhi aturan protokol dan tetap harus berdo'a pada Sang Pencipta agar tetap sehat dan di lindungi dari wabah yang sedang melanda. Karena semua adalah Kuasa-Nya. Tidak Setuju karena kita harus tetap bekerja tapi kalo perusahan mengajurkan WFH ya gapapa”.

Boleh jadi pernyataan beragam di atas menunjukkan adanya kebiasaan yang tiba-tiba berubah harus diikuti secara pasrah agar bisa terhindar dari bencana yang bisa menimpa diri dan orang-orang dekatnya. Konsep \#Di Rumah Aja terkait dengan persoalan kelanjutan hidup, terkait dengan profesi atau pekerjaan. Berhubung dengan sarana dan fasilitas rumah untuk menjamin kenyamanan konsep itu. Sepertinya ungkapan di atas merupakan apologetika yang perlu solusi holistic agar Konsep Di Rumah Aja bisa memenuhi targetnya. Konsep Di rumah aja sebenarnya merupakan bentuk daro lock down yang diterapkan oleh pemerintah. Kebijakan lockdown juga mengatur masyarakat agar selalu berada di rumah dan melarang keberadaan masyarakat di luar rumah terkecuali diperlukannya kegiatan yang sangat tidak memungkinkan dilakukan di rumah (Ramadhan, 2020). Adapun kebijakan lockdown ini menimbulkan dampak positif dan negatif. Dampak negatif yang pertamakali bisa langsung 
dirasakan akibat wabah virus corona ini adalah merosotnya pertumbuhan ekonomi. Adapun Dampak positif dari kebijakan lockdown adalah pemerintah dapat mengurangi jumlah masyarakat yang terdampak virus Covid-19, karena mengurangi aktifitas diluar dapat menjaga resiko penularan yang tinggi (Yunus and Rezki 2020).

Terkait dengan pemahaman warga masyarakat dengan kesadaran adanya bahaya coid-19 para responden menyatakan pemahaman dan sarannya; Sudah menyadari, ya sarannya yang penting selalu menjalankan protocol kesehatan dan ingat 3M. Sudah menyadari, Saran untuk masyarakat adalah agar lebih berhati hati lagi tetap menjaga kesehatan, jaga pola makan, tidak lupa mengkonsumsi vitamin, selalu menerapkan protokol kesehatan memakai masker, mencuci tangan, menjaga jarak. Saran untuk pemerintah, tetap mengingatkan kedisiplinan hidup sehat untuk warga masyarakat, agar sehat untuk kita semua (Tuti, 2020). Sudah menyadari makanya banyak menggunakan masker, untuk pemerintah ya secepatnya memutuskan mata rantai virus ini. Masih belum semua karena saya liat masih banyak yang engga menggunakan masker, untuk pemerintah ya paling sosiaisasi lagi ke masyarakat mengenai bahaya virus corona ini.

Pemerintah berupaya menanggulangi bahaya covid dengan mengadakan vaksin baik dari dalam maupun luar negeri untuk menjaga rakyat agar sehat. Ketika diminta kesediaan, saran dan pendapatnya, beberapa responden mengungkapkan,
"Ya ga papa mas kalo misalkan gratis dan di jamin aman. Apabila setelah di vaksin kita bisa lebih baik kenapa tidak, pada dasarnya pemerintah menyiapkam vaksin untuk kesehatan semua orng agar terhindar dari bahaya covid 19. Kalau di vaksin kita bisa lebih aman kenapa tidak. Iya tidak apa-apa asal di jamin aman."

Selain pernyataan setuju untuk divaksin dengan beberapa catatan, berikut pendapat yang berbeda,

"Tidak setuju, karena vaksin dari virus ini belum teruji. Tidak setuju karena vaksi masih belum jelas. Tidak, Karena di berbagai kabar berita masih belum ada obatnya sedangkan vaksin ini juga belum teruji. Tidak, karena berita yang saya dapat masih belum jelas".

Gelagat dari pernyataan tersebut walau tidak dihitung secara kuantitatif menunjukkan masih ada kegalauan dan belum percayanya pada kualitas vaksin yang selama ini distigmatisasi belum layak digunakan pemerintah. Alhasil upaya untuk meyakinkan masyarakat tentang pentingnya vaksin, kegunaan dan manfaat serta dipandang manjur termasuk halal adalah target yang harus dilampau dalam meyakinkan calon pengguna vaksin. Pendekatan untuk meyakinkan masyarakat pengguna vaksin harusnya lintas 
sectoral, bukan hanya pendekatan Kesehatan dan politik semata. Pastinya hal itu sudah menjadi wacana tim komunikator dari gugus covid. Hal ini sebenarnya sudah dilakukan sebagaimana kita lihat di media-media yang live dan massif.

Akhir dari upaya 3M yang diharapkan bisa dilakukan oleh masyarakat merupakan target untuk dipahami dan amalkan sehingga lingkungan tidak menjadi tempat sebaran covid-19. Responden selalu mengupayakan sebagaimana rentetan testimoni berikut; Mencuci tangan, menjaga jaga jarak dan memakai masker itu saja sudah cukup. Jaga jarak dan cuci tangan setiap saat. Minum vitamin, jaga jarak, memakai masker. Cuci tangan, pakai masker jika keluar rumah. Tetap jaga jarak, memakai masker dan cuci tangan setiap saat. Menjaga kebugaran tubuh, minum vitamin, mengurangi interkasi social dan cuci tangan setiap saat.

\section{KESIMPULAN DAN REKOMENDASI}

Berdasarkan paparan di atas dapat diketahui bahwa masyarakat Desa Sutawinangun Kecamatan Kedawung Kabupaten Cirebon baru menyadari bahwa covid-19 sangat berbahaya dengan penyebaran yang cepat setelah desanya dinyatakan zona merah sebagai bukti adanya warga yang terpapar, adanya rencana tempat isolasi penderita covid-19 di desanya yang kemudian keberadaannya ditolak, dan berhasilnya gugus tugas covid-
19 dalam mensosialisasikan protocol Kesehatan sebagai bentuk penyadaran.

Dari hasil observasi menunjukkan sebenarnya masyarakat cukup kooperatif dalam upaya memutus rantai covid-19 di lingkungan warga Sutawinangun Kecamatan Kedawung Kabupaten Cirebon baik dengan menjaga protocol kesehatan, menjalani rapid, swab dan vaksin yang aman. 


\section{DAFTAR PUSTAKA}

Armiani, Sucika, Siti Rabiatul Fajri, Akhmad Sukri, and Baiq Yulia Pidiawati. 2020. "Pelatihan Pembuatan Masker Sebagai Upaya Antisipasi Penyebaran Covid-19 Di Desa Anyar Kabupaten Lombok Utara." Jurnal Pengabdian UNDIKMA 1(1):22-27.

Burhan Bungin , 2001, Metode penelitian sosial. Airlangga Universitas, Press.

Ekp, Address Gedung, F. E. B. Unsyiah, Kopelma Darussalam, Banda Aceh, Pandemi Covid, and D. I. Indonesia. 2020. "Ekonomi Dan Kebijakan Publik Indonesia." 7(1):36-53.

https://megapolitan.kompas.com/read/2020 /10/18/20582011/ini-alasan-wargasabang-tolak-hotel-jadi-tempatisolasi-pasien-covid-19?page $=$ all..

John W. Creswell, 2009 Research, Desigh, Pendekatan Kualitatif, Kuantitatif dan Mixed.Yogyakarta: Pustaka Pelajar.

Karo, Marni Br. 2012. "Perilaku Hidup Bersih Dan Sehat ( PHBS ) Strategi Pencegahan Penyebaran Virus Covid-19." 1-4.
Pencegahan, Pendampingan, and Penyebaran Covid. 2020. "Pendampingan Pencegahan Penyebaran Covid - 19 Di Desa Errabu Kecamatan Bluto Kabupaten Sumenep 1).” 01(01):71-77.

Pencegahan, Strategi, and Penyebaran Covid- Di. 2020. "Strategi Pencegahan Penyebaran Covid-19 Di Lembaga Pemasyarakatan." 7(3): 518-22.

Sholikah, Nur, and Putri Suni. 2020. "KESIAPSIAGAAN INDONESIA MENGHADAPI POTENSI PENYEBARAN CORONA.” (49).

Telaumbanua, Dalinama. 2020. "Urgensi Pembentukan Aturan Terkait Pencegahan Covid-19 Di Indonesia." 12(1):59-70.

Yunus, Nur Rohim, and Annissa Rezki. 2020. "Kebijakan Pemberlakuan Lock Down Sebagai Antisipasi Penyebaran Corona Virus Covid19." SALAM: Jurnal Sosial Dan Budaya Syar-I 7(3). 